\title{
The role of the infectious disease physician in abdominal wall repair using prosthetic material after clean-contaminated surgery
}

\author{
Daniel Ion*, Răzvan Vasile Stoian, Simona Elena Albu, Alexandra Bolocan, Dan Nicolae Păduraru \\ From The 10th Edition of the Scientific Days of the National Institute for Infectious Diseases "Prof Dr Matei \\ Bals" \\ Bucharest, Romania. 15-17 October 2014
}

\section{Background}

Use of antibiotic prophylaxis when prosthetic implants are present at the abdominal wall was a controversial decision. It is a delicate matter since parietal prosthetics frequently associate surgical visceral interventions (cholecystectomy, appendectomy, enterectomy/enterorrhaphy, and colectomy).

\section{Methods}

This study was carried out in the Surgery and Emergency Clinic III of the University Emergency Hospital Bucharest. It is based on a 5 year experience (2010-2014), retrospective evaluation on 224 incision hernias resolved with prosthetic material, of which 216 in a clean environment and 28 in a clean-contaminated environment. For all the cases the antibiotic prophylaxis management was decided by a mixed team: general surgeon and infectious disease physician.

\section{Results}

Results plead for the rational and selective use of antibiotics for the patients that require prosthetic material and draw attention to the extremely favorable results of the collaboration between different specialty physicians.

\section{Conclusion}

Even though the initial dogma was that all alloplastic grafts need "protection" provided by the antibiotics, recent approaches tend to be more selective and permissive.
Published: 15 October 2014

doi:10.1186/1471-2334-14-S7-P81

Cite this article as: Ion et al:: The role of the infectious disease physician in abdominal wall repair using prosthetic material after clean-contaminated surgery. BMC Infectious Diseases 2014 14(Suppl 7):P81.

* Correspondence: dr.daniel.ion@gmail.com

University Emergency Hospital of Bucharest, Romania

Submit your next manuscript to BioMed Central and take full advantage of:

- Convenient online submission

- Thorough peer review

- No space constraints or color figure charges

- Immediate publication on acceptance

- Inclusion in PubMed, CAS, Scopus and Google Scholar

- Research which is freely available for redistribution

Submit your manuscript at www.biomedcentral.com/submit
C Biomed Central 